\title{
Evaluating watershed health in Costa Rican national parks and protected areas
}

\author{
T. J. Jovanelly ${ }^{1} \cdot$ L. Rodríguez-Montero $^{2} \cdot$ R. Sánchez-Gutiérrez ${ }^{3} \cdot$ L. Mena-Rivera $^{4} \cdot$ D. Thomas $^{1}$
}

Received: 6 May 2020 / Accepted: 13 July 2020 / Published online: 11 August 2020

(c) Springer Nature Switzerland AG 2020

\begin{abstract}
Although the biodiversity of Costa Rican national parks, forests, and wetlands has been extensively surveyed, there has not been a watershed assessment that reflects their baseline water quality. Undoubtedly, the influx of 3.1 million visitors annually can lead to deterioration. Additionally, the country's movement toward $100 \%$ carbon neutral energy means reliance on capturing water for the production of hydroelectricity. The missing hydrologic data set is of immediate concern, as watershed health predicts total ecosystem health. This field-based project measures eight parameters ( $\mathrm{pH}$, temperature, fecal coliform, dissolved oxygen, biochemical oxygen demand, nitrates, total phosphates, turbidity) needed to assign a watershed quality index (WQI) value at nine national parks or protected areas. Overall, the WQI for the systems surveyed reflect good water quality. Results compared with US Environmental Protection Agency (EPA) and World Health Organization (WHO) drinking water standards indicate limited levels of contamination at most sites, with elevated signatures of nitrates, phosphates, turbidity, and/or fecal coliforms at few. The parks selected include coastal lowlands and central highlands; they also experience diverse tourist activities, degrees of use, and forest type that are challenges when managing land sustainably.
\end{abstract}

Keywords Cost Rica $\cdot$ Hydroelectricity $\cdot$ National parks $\cdot$ Water quality index

\section{Introduction}

Costa Rica $\left(51,100 \mathrm{~km}^{2}\right)$ is an equatorial country that is located in Central America (Fig. 1). It is known best for its rich biodiversity and assorted natural landscape. The 500,000 species that are found in this small country represent $4 \%$ of the total species estimated worldwide (DeClerck et al. 2010; Kohlmann et al. 2010). The Cordillera de Talamanca mountain range (peak elevation 3820 masl) acts as a drainage divide for all river systems, whereby the eastern slope runoff enters the Caribbean Sea, while the western slope runoff enters into the Pacific Ocean. This extensive

T. J. Jovanelly

tjovanelly@berry.edu

Berry College, Mount Berry, GA, USA

2 Universidad Nacional, Heredia, Costa Rica

3 Water Resources Management Laboratory and Stable Isotope Research Group, Chemistry Department, Universidad Nacional, Heredia, Costa Rica

4 Water Resources Management Laboratory, School of Chemistry, Universidad Nacional, Heredia, Costa Rica northwest-southeastern mountain belt significantly impacts area climate with the Caribbean flank receiving $>300 \mathrm{~cm}$ of annual precipitation and the Pacific flank receiving $<300 \mathrm{~cm}$ (Calder 2007).

Approximately, 24\% of the land in Costa Rica is designated as a national park or protected area, most of which was gazetted in the 1980 s as tourism began to boom. In 2019, tourism in Costa Rica accounted for an estimated total earnings of $\$ 2.8$ billion USD that was spent by 3.1 million visitors (per 2019 Census). Of those 3.1 million visitors, approximately half visited national parks and protected areas (Hunt and Harbor 2019; Farrell and Marion 2001). While the promotion of eco-tourism has supplied locals with employment, the country has met with challenges in their sewage infrastructure, the need for more energy, and necessity of water allocation during sustained drought, such as that of the recent day (2014-2017). With that stated, the country has also recognized that an influx of visitors over half of the country's population can cause the landscape to deteriorate if not protected (World Bank 2019).

In 1995, a governmental body was created to help manage the land called the Ministry of the Environment and Energy (MINAE). Subsequently, another group was formed called 


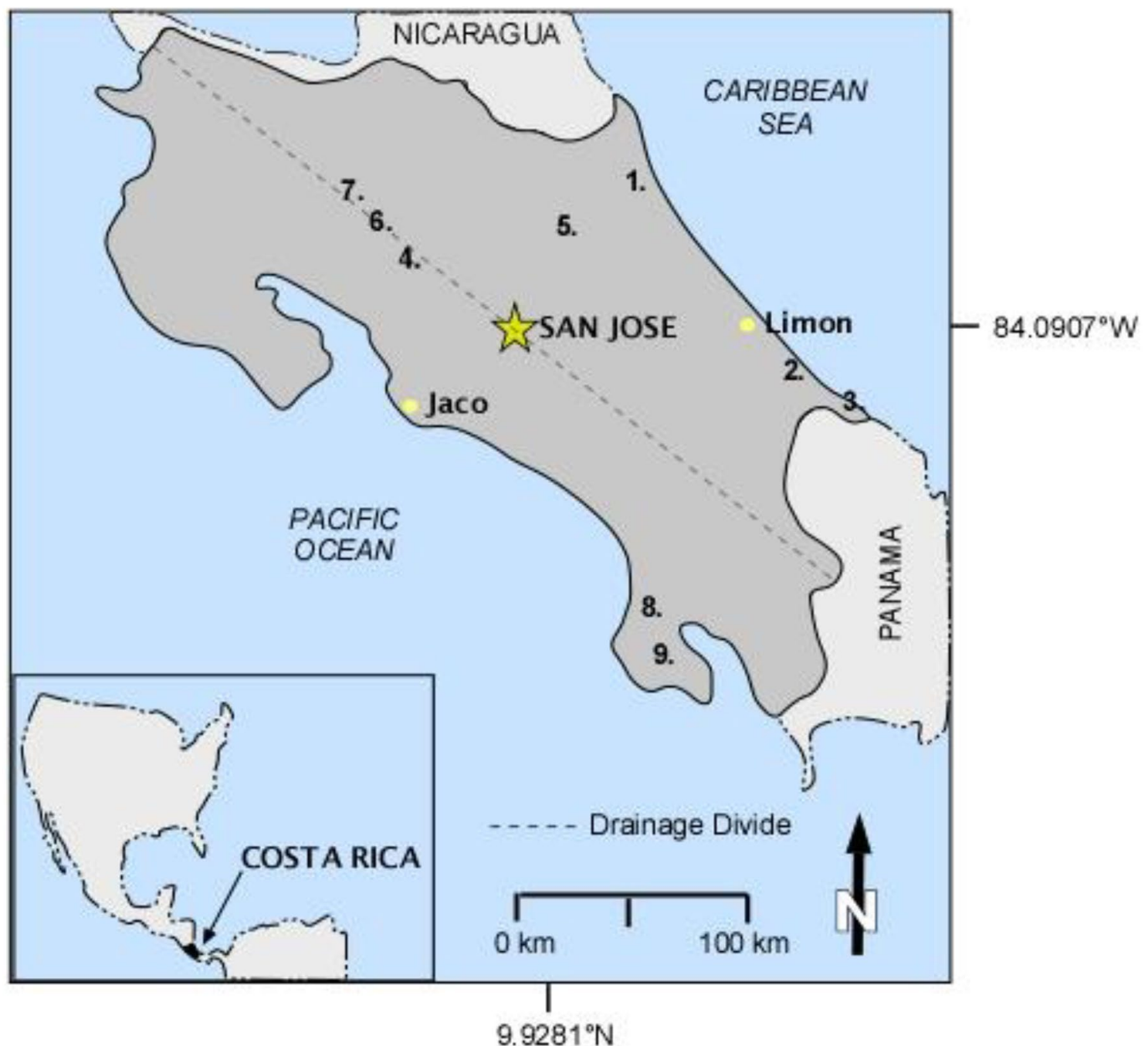

Fig. 1 Location map of sampled national parks (NP), national wetlands (NW), forest reserves (FR), and wildlife refuges (WR). 1. Tortuguero NP, 2. Cahuita NP, 3. Gandoca-Manzanillo WR, 4. Mon-

the National System of Conservation Systems (SINAC) which is responsible for the conservation and sustainability use of the country's biodiversity. In total, however, there are over 20 governmental agencies dealing with water resources (Bower 2014). The major dilemma with governance is the absence of a single institution with full responsibility for planning and management of watershed resources and current water laws that have become obsolete (EsquivelHernández et al 2018; Guzman-Arias and Calvo-Alvarado 2013).

While Costa Rica has been recognized as one of the more environmentally conscious countries in the developing world (winner of the Ethical Traveler Destination award in 2011 and 2012, for example), the government's push for it to become the first carbon-neutral country by 2021 means increasing hydroelectricity by $20 \%$ in the next teverde Cloud FR, 5. Braulio Carrillo NP, 6. Arenal Volcano NP, 7. Tenorio Volcano NP, 8. Terraba Sierpe NW, 9. Corcovado NP

5 years (Worldwatch Institute 2017). It is known that dam construction is one of the primary drivers that alters environmental conditions of river ecosystems and may affect its water quality and water self-purification capacity (Brewitt and Colwin 2019; Wei et al. 2009). Water self-purification capacity refers to the maximal capacity of a river segment to take in pollutant without any risk and depends on several factors such as flow volume, flow velocity, pollutant concentration, pollutant decomposition rate, etc. These factors are altered with dam construction. Moreover, Winton et al. (2019) suggest that changes to the stream channel morphology and/or the building of a reservoir can negatively impact water quality through two main processes: the trapping of nutrients and sediments, and thermal stratification. The ecological consequences of dams stem primarily from river fragmentation, stream de-watering, and downstream 
alterations (Gierszewski et al. 2020; Anderson et al. 2006; Dynesisus and Nilsson 1994). It is also well documented that dams affect the distribution and abundance of aquatic biota, especially migratory species (Jones and Bull 2020; Pereira et al 2020). Additionally, an alarming and highly referenced climate model created by the University of Massachusetts-Climate System Research Center predicts that the Costa Rican high elevation Pacific slopes and the Caribbean lowlands are likely to receive $30 \%$ less precipitation within the next 50-100 years (Stan et al. 2020; Castillo et al. 2017; Karmalkar et al. 2008). Thus, the predetermined functionality of the dams is likely to change within a half of century.

While the biodiversity of the national parks and forested protected areas has been extensively and intensely surveyed, there is a recent country-wide interest on the collection of baseline water quality data through organized watershed assessment in Costa Rica (Mena-Rivera et al. 2017, 2018). Although the building of a hydroelectric facility or dam in a national park (or similar) is unlikely, the concern is that streams adjacent to preserved landholdings are often targeted for construction and channelization that alters the flow entering the park (Opperman et al. 2019; Anderson et al. 2006). Moreover, according to Bower (2014), the country has not yet developed a plan of sustainable water use whereby considering its future demands against the availability and quality of water. Unanswered, this could prove problematic as only $8.2 \%$ of the raw sewage in Costa Rica is treated before it is released into the environment, highlighting the need for sanitation infrastructure development and monitoring (Mena-Rivera et al 2018; Bower 2014). Forest cover and wetlands adjacent to biological corridors and national parks continue to be threatened by contaminants: from heavy agricultural activities such as sugarcane, banana and pineapple plantations, rice, citrus, melon, and livestock (Mena-Rivera and Quirós-Vega 2018; Allen and Vásquez 2017; Mitsch et al. 2008). In a 2013 ecosystems review, Costa Rican hydrology experts, Guzman-Arias and CalvoAlvarado, suggest that data collection on the watersheds is the missing link to manageable and sustainable use. Additionally, data sets representing water quality is an immediate concern because watershed health acts as a predictor for total ecosystem health (Kolok et al 2020; EPA 2016; Woodall et al. 2011). Vibrant watersheds provide critical services, such as clean drinking water, productive fisheries, and outdoor recreation, which support economies, environment, and quality of life. Understanding that the quality of the water is the 'canary in the cage' has been the message overlooked by undeveloped and developing countries (Jovanelly et al. 2015).

Overall, the aim of this project is to highlight the importance of including hydrological system health in Costa Rican forest conservation. The project is timely because the water quality index (WQI) has not been used to communicate watershed health in Costa Rica. The WQI is a unitless number ranging from 1 to 100 that reflects the overall health of a system by assigning weighted values to the eight parameters $(\mathrm{pH}$, temperature, fecal coliform, dissolved oxygen, biochemical oxygen demand, nitrates, total phosphates, turbidity) measured using field instrumentation. A higher WQI number is indicative of better water quality (100-90 is deemed excellent water quality, for example). Because WQI combines parameters into a single rank value (poor, moderate, etc.), the WQI serves as a straightforward way of communicating changes in watershed health to forest communities and to measure changes in national parks and protected areas.

\section{Study areas}

The national parks and prsotected areas selected for this study reflect both the Caribbean (Tortuguero National Park, Cahuita National Park, Gandoca-ManzanilloWildlife Refuge) and Pacific (Corcovado National Park, Térraba Sierpe National Wetland) lowlands, as well as the Central Highlands (Monteverde Cloud Forest Reserve, Arenal Volcano National Park, Braulio Carrillo National Park, Tenorio Volcano National Park) (Fig. 1). These nine national parks or protected areas also demonstrate the diversity of touristic activities, varying degrees of visitation, and assortment of forest types that challenge the Costa Rican government when managing land sustainably. Additionally, these preserves are contained within distinct watersheds (UNESCO 2007).

\section{Caribbean coast}

The Costa Rican Caribbean coast is located on the country's eastern shoreline and is the result of subduction process between the Cocos and Caribbean plates and the development of volcanic arcs, shallow deposits, and turbidity environments around $65 \mathrm{Ma}$. The study area encompasses two geological regions, the Caribbean Basin and Limón Basin, to form a $50 \mathrm{~km}$-wide depression extending from broad alluvial plains in the north to marine carbonate platforms of the southeast. The carbonate platforms are of marine origin, formed by Plio-Pleistocene reef limestone rocks that have been gradually raised by slow uplift punctuated by sudden vertical movements due to regional tectonic activity (Quesada-Román and Pérez-Briceno 2019). The most common soil orders found along the coast are of low-porosity types such as entisols and inceptisols, although organic-rich histosols have been identified in some flood plain areas. The tropical forests (average rainfall $477 \mathrm{~cm}$ ) along the Caribbean coast provide an environment to support extensive pastures for livestock and banana plantations. The coastal lagoons of the Caribbean coast exhibit characteristics of estuaries that 
have been closed by sedimentation, like that at Tortuguero National Park (Location 1; $10^{\circ} 26^{\prime} 40^{\circ} \mathrm{N}, 83^{\circ} 30^{\prime} 36^{\circ} \mathrm{W}$ ). This national park has over $32 \mathrm{~km}$ of coastline that is a habitat for sea turtles. Tortuguero National Park $\left(311 \mathrm{~km}^{2}\right)$ is bordered by the Barra del Colorado Wildlife Refuge to the north and the Parismina River and Cariari National Wetlands to the south. The Tortuguero River is a primary freshwater source for this area and flows into the Caribbean Sea. The morphology of Location 2 (Cahuita National Park; 9 $9^{\circ} 44^{\prime} 11^{\prime \prime} \mathrm{N}$, $82^{\circ} 50^{\prime} 19^{\prime \prime} \mathrm{W}$ ) and Location 3 (Gandoca-Manzanillo Wildlife Refuge; $9^{\circ} 37^{\prime} 48^{\prime \prime} \mathrm{N}, 82^{\circ} 38^{\prime} 56^{\prime \prime} \mathrm{W}$ ) is best described by their white sand beaches now in place due to the coastal erosion of coral reefs. Cahuita National Park is $11 \mathrm{~km}^{2}$, but is most known for its beach access for offshore protected coral reefs. The remote Gandoca-Manzanillo Wildlife Refuge protects $15 \mathrm{~km}$ of the southern Caribbean coast, extending from Manzanillo to the Panama border. The refuge encompasses $50 \mathrm{~km}^{2}$ of lowland tropical rainforest, wetlands, and mangrove swamps.

\section{Central highlands}

The Cordillera de Talamanca extends $200 \mathrm{~km}$ along the Central Highlands of Costa Rica and is the tallest mountain range in Costa Rica with volcanic peaks reaching $3500 \mathrm{~m}$ (average $2000 \mathrm{~m}$ ). The complicated formation of the range introduces Eocene age ( $33.9 \mathrm{Ma})$ volcanic rocks that are followed by igneous intrusive batholiths and later the erosional formation of rocks with sedimentary lithologies (Alvarado and Gans 2012). The shape of drainage basins within the Cordillera de Talamanca were further influenced by Pleistocene glacial and periglacial landscapes that scoured deep U-shaped valleys that are sometimes lined with an impermeable loess layer. The overall relief of the mountain range is unusual in that the shape is asymmetrical in cross section: the SW flank is steep, and the NE slope is moderately inclined.

A classic mountain cloud forest on the southern side of Cordillera de Talamanca called Monteverde Cloud For-

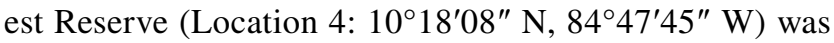
sampled in both 2018 and 2019. Monteverde Cloud Forest Reserve was established in 1972 with an area of $3.3 \mathrm{~km}^{2}$ and has expanded to cover $142 \mathrm{~km}^{2}$ at the present day. This area contains eight different ecotones atop of the Talamanca Continental Divide that separates the drainage from the Pacific Ocean on the western flank from that of the Caribbean Sea on the east. This site receives $260 \mathrm{~cm}$ rainfall annually and is at an elevation of $\sim 1600$ masl (Guswa et al. 2007).

Three volcanic national parks were sampled that include: Arenal Volcano National Park (location 5: $10^{\circ} 31^{\prime} 59^{\prime \prime} \mathrm{N}$, $84^{\circ} 43^{\prime} 13^{\prime \prime} \mathrm{W}$ ), Braulio Carrillo National Park (location 6: $10^{\circ} 09^{\prime} 06^{\prime \prime} \mathrm{N}, 84^{\circ} 05^{\prime} 39^{\prime \prime} \mathrm{W}$ ), and Tenorio Volcano National Park (location 7: $10^{\circ} 42^{\prime} 43^{\prime \prime} \mathrm{N}, 85^{\circ} 01^{\prime} 04^{\prime \prime} \mathrm{W}$ ). Arenal
Volcano National Park is $120 \mathrm{~km}^{2}$ and is located within the larger $2039 \mathrm{~km}^{2}$ Arenal Conservation Area. Arenal Volcano is an active andesitic stratovolcano that reaches $1140 \mathrm{~m}$. The volcano was dormant for hundreds of years prior to its last eruption in 1968. Fumaroles and hot springs are still present in the area. Nearby, Lake Arenal is the largest lake in Costa Rica at $85 \mathrm{~km}^{2}$ with a depth between 30 and $60 \mathrm{~m}$. In 1979, this reservoir tripled in size when it was expanded to accommodate a hydroelectric dam that was installed. The Lake Arenal Dam produces approximately $12 \%$ of the country's total electricity and is the third largest producer in the country at $180 \mathrm{MW}$ annually. The area receives approximately $406 \mathrm{~cm}$ per year.

Braulio Carrillo National Park was gazette in 1978 and covers $183 \mathrm{~km}^{2}$, including the inactive volcano that peaks at $2900 \mathrm{~m}$. The forest is supported by $203 \mathrm{~cm}$ per year of rainfall and is unique in that the habitats represent a cloud forest, a regenerating tropical rainforest lowland and a tropical rainforest upland. The Sucio River is the main river that runs through the park and is named after sulfur deposits found on the nearby Volcano Irazú. The Sucio River is a tributary of the much larger Río San Juan.

Tenorio Volcano National Park was created to protect the pre-montane forest from logging in 1976 and is $130 \mathrm{~km}^{2}$. The park contains four volcanic cones with a maximum height of $1916 \mathrm{~m}$. The volcanic complex has been dormant since 1997 when microseismicity was last reported. Running through the park is a popular tourist destination called Río Celeste that is supported by the $475 \mathrm{~cm}$ of rainfall the area receives annually. It is a $14 \mathrm{~km}$-long river that is formed by the convergence of Quebrada Agria and Río Buena Vista. Río Celeste is a milky blue color from the high amounts of aluminum and silicates that are suspended in the water (Castellón et al. 2013). Additionally, hot springs and fumaroles can be found throughout the national park.

\section{Pacific coast}

The Pacific coastal region of Costa Rica is characterized by an active convergent plate margin of complex origin starting in the mid-Miocene approximately 8 Mya. Here, a collisional boundary has formed between the Caribbean and Cocos tectonic plates, whereby the rate of subduction is estimated to be $9.5 \mathrm{~cm}$ per year (Wells et al. 1988). The intensity of this subduction zone has translated into significant amounts of Quaternary deformation seen along the southwestern coastal region that include fault scarps displacing fluvial terraces and changes to the deposition of colluvial soils in areas of collisional response (Harpster et al. 1981). These shifts in surficial processes influence drainage basin shape by creating steep slopes and irregular longitudinal river profiles that are characterized by concave and convex reaches. 
The Pacific Coast of Costa Rica has a large number of embayments that provide shelter from wind and wave activity that can favor mangrove development (Niekerk et al. 2020; Polanía 1993). Uniquely, mangroves are more developed in this ecoregion than further up the coastline due to the higher rate of freshwater inflow that reduces salt accumulation in the mangroves by increasing evapotranspiration (Jimenez 1999). Térraba Sierpe National Wetland (Location $8: 8^{\circ} 50^{\prime} 17^{\prime \prime} \mathrm{N}, 83^{\circ} 33^{\prime} 14^{\prime \prime} \mathrm{W}$ ) is the largest mangrove system in Costa Rica $\left(270 \mathrm{~km}^{2}\right)$ and is among the largest in Central America. This National Wetland includes the Térraba-Sierpe river delta that was used for agricultural planting for six decades prior to the wetland being gazetted in 1994 with an annual net loss of 40 ha per year between 1948-1994 (Acuna-Piedra and Quesada-Roman 2017). Rainfall and tidal fluctuations directly impact mangrove ecosystems. This ecoregion receives an average of $368 \mathrm{~cm}$ of rain annually and has a mean tidal gain of $3.5 \mathrm{~m}$ (Polanía 1993).

The Osa Peninsula is south of the mangrove forest and is home to the largest remaining primary forest $\left(424 \mathrm{~km}^{2}\right)$ on the Pacific Ocean at Corcovado National Park (Location 9: $8^{\circ} 30^{\prime} 22^{\prime \prime} \mathrm{N}, 83^{\circ} 35^{\prime} 24^{\prime \prime} \mathrm{W}$ ). About $85 \%$ of this national park is considered pristine and it is bisected by numerous small streams and rivers that drain the ridges along the eastern park border to the Pacific Ocean. Other inland waters include a large marsh, a palm swamp, and several small estuaries (Constantz et al. 1981). This lowland tropical forest (average rainfall $500 \mathrm{~cm}$ ) became protected in 1975 and was saved from adjacent logging activity.

\section{Materials and methods}

Data for eight parameters, dissolved oxygen (DO), biochemical oxygen demand (BOD), pH, turbidity, nitrates, phosphates, fecal coliform, and temperature, were used to calculate the WQI as specified under the National Sanitation Foundation guidelines (Mitchell and Williams 2000; Brown et al. 1970). WQI reflects the overall health of a water system by assigning weighted values to the parameters.

Water quality data were collected in each of the national parks or protected areas by the research team once or twice over two wet seasons in 2018 and 2019 (Fig. 2). During each site visit, the researchers collected water samples. The sampling locations depended upon accessibility. The six water quality parameters $(\mathrm{DO}, \mathrm{pH}$, turbidity, nitrates, phosphates, temperature) were measured on site using field instrumentation (Fig. 3). A handheld Texas Instrument Nspire CX calculator was used with corresponding dissolved oxygen, $\mathrm{pH}$, and turbidity probes that connected directly to the instrument allowing for immediate field sampling. All probes were calibrated prior to each field visit using the manufacturer's instructions. A portable LaMotte SMART
3 Colorimeter was used to measure nitrate and phosphorus at the field location. The instrument was calibrated for each parameter independently prior to use according to the instrument guidelines. Nitrates were determined using a zinc reduction method and the phosphorus was established using the vanadomolybdophosphoric acid method. Temperature was measured on-site using a mercury thermometer.

At each sample site, water was collected in $250 \mathrm{ml} \mathrm{Nal-}$ gene amber sample bottles and transported to the laboratory. The fecal coliform test was completed in the laboratory (usually within 4 hof sample collection) using $3 \mathrm{M} ®$ Petrifilm Coliform Count Plates by inoculating $1 \mathrm{ml}$ water sample according to the manufacture's guidelines. The plates were incubated at room temperature for $24 \mathrm{~h}$. After $24 \mathrm{~h}$ the colonies on the slide were counted and recorded.

The remaining water samples were capped tightly and placed in a dark cabinet for 5 days and incubated at room temperature. The water sample was tested again after 5 days for DO using the TI-Nspire CX calculator and probe, and BOD calculated. After sampling, a baseline WQI (that represents seasonal variability) for each forest reserve was established.

Data analysis was carried out by computing the descriptive and inferential statistic; the latter was done by a permutation test (Good 2009; Blair et al. 1994) where differences of mean values for the WQI and significant parameters were tested among national parks locations. Also multivariate analysis (principal component analysis, PCA) was computed to identify which parameters can explain the main variability within the obtained results for WQI.

\section{Results}

The WQI monthly averages for each of the nine national parks or protected areas are displayed in Fig. 2; monthly averages of the eight WQI parameters measured are found in Fig. 3.

\section{Caribbean locations}

The WQI at Tortuguero National Park (Location 1, Fig. 1) ranged between 73.0 and $77.0 \%$. Of the three sample sites, all fell in sthe good range. Dissolved oxygen ranged between 5.00 and $5.80 \mathrm{mg} / \mathrm{L}$ and was lowest in the mangrove swamp $(5.30 \mathrm{mg} / \mathrm{L})$. BOD ranged between 0.10 and $0.3 \mathrm{mg} / \mathrm{L}$, ranking the overall BOD levels between 99 and $100 \%$. The water acidity ranged between a pH of 5.98 and 6.26 resulting in WQI values for $\mathrm{pH}$ from below average (54\%). The temperature of the surface water sampled was $26-28{ }^{\circ} \mathrm{C}$. Nitrates were found in all of the samples at Tortuegero National Park (1.0-6.0 mg/L). Site TG1, a mangrove swamp, had elevated nitrates compared to sites TG2 and TG3. The lowest 


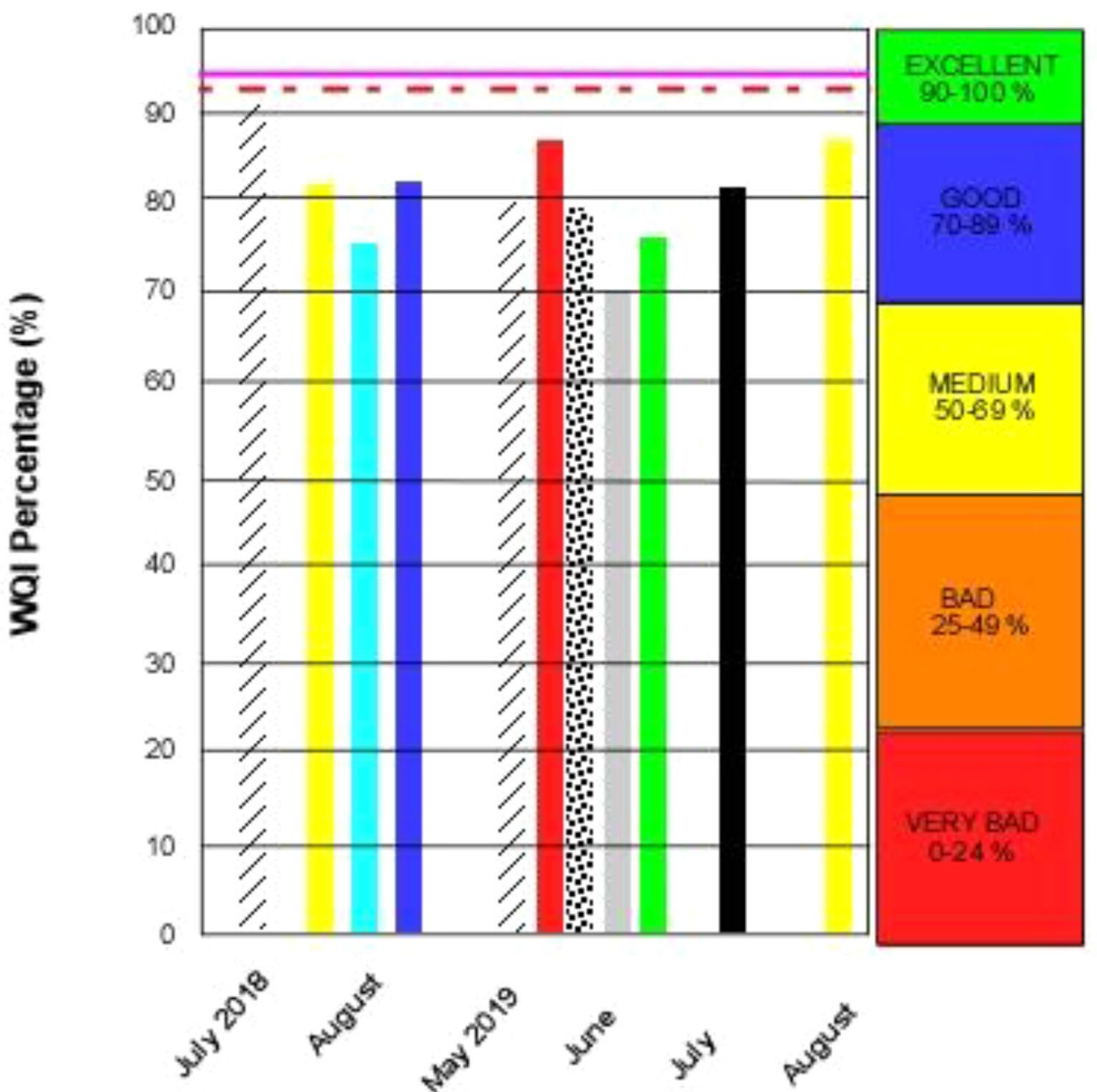

Month

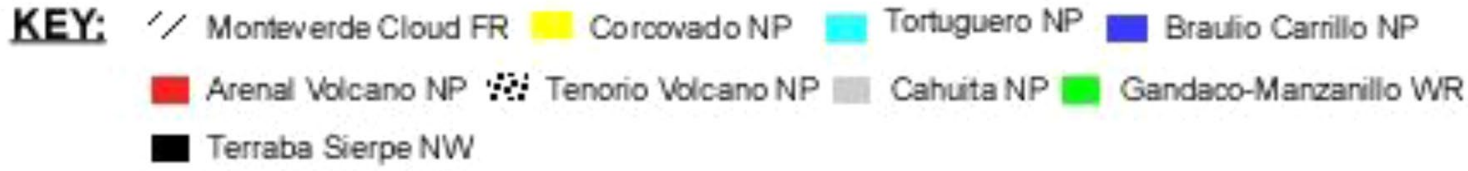

- - EPA WOl using mirimum values

WHO WQI using minimum values

Fig. 2 Average monthly water quality indices for nine national parks (NP), national wetlands (NW), forest reserves (FR), or Wildlife refuges (WR) as compared to the USEPA and WHO WQI calculated using minimum values from Table 1 for drinking water

nitrates $(1.0 \mathrm{mg} / \mathrm{L})$ of all the sample locations was found in the Tortuguero River. Phosphates ranged between 1.0 and $3.0 \mathrm{mg} / \mathrm{L}$. July recorded the overall lowest levels of phosphates. Fecal coliform levels at Tortuguero National Park produced excellent WQI index values at $100.0 \%$ as all of the samples were devoid of fecal coliform. The water from Tortuguero National Park had turbidity as high as 36.90 NTU and the lowest documented turbidity was 32.90 NTU.

The average WQI of Cahuita National Forest (Location 2, Fig. 1) ranged between 58.0 and $76.0 \%$, representing medium to good water quality. Measured dissolved oxygen ranged between 2.7 and $8.40 \mathrm{mg} / \mathrm{L}$. Low dissolved oxygen levels occurred at $\mathrm{CH} 3(2.70 \mathrm{mg} / \mathrm{L})$ and the other six sites averaged $7.8 \mathrm{mg} / \mathrm{L}$. Little change occurred between the initial and final DO in the BOD test; all values reported are $<1.0 \mathrm{mg} / \mathrm{L}$. The $\mathrm{pH}$ ranged between 7.09 and 7.58. The highest nitrate concentration was $50.0 \mathrm{mg} / \mathrm{L}$ at $\mathrm{CH} 1$, while the lowest was $11.0 \mathrm{mg} / \mathrm{L}$ at $\mathrm{CH} 6$. Phosphate concentrations ranged between 7.0 and $27.0 \mathrm{mg} / \mathrm{L}$. Fecal coliform concentrations were detected at all sites and ranged between 25 and 90 colonies/100 ml. Turbidity was also elevated (17.30-78.90 NTU). 
Fig. 3 Values measured for each parameter at field sites correlating to Figs. 1 and 2. Monteverde Cloud FR (MV), Corcovado NP (C- for 2018 data; CB for 2019 data), Tortuguero NP (TG), Braulio Carrillo NP (B), Arenal Volcano NP (A), Tenorio Volcano NP (T), Cahuita NP (CH), Gandoca-Manzanillo WR (GM), Térraba-Sierpe NsW (TS). The values are grouped in cases where the range is $0.5 \mathrm{mg} / \mathrm{L}$ or less, $1 \mathrm{NTU}$ or less, 5 colonies $/ 100 \mathrm{~mL}$ or less, or $1^{\circ} \mathrm{C}$

The average WQI at Gandoca-Manzanillo Wildlife Refuge (Location 3, Fig. 1) was good (73.0-85.0\%). Measured dissolved oxygen ranged from 7.80 to $9.0 \mathrm{mg} / \mathrm{L}$ at all sites except GM1, which showed lower dissolved oxygen levels $(6.90 \mathrm{mg} / \mathrm{L})$. BOD at Gandoca-Manzanillo Wildlife Refuge ranged between 0.10 and $0.20 \mathrm{mg} / \mathrm{L}$. The $\mathrm{pH}$ was within 6.86-7.49. Elevated nitrates $(8.0-50.0 \mathrm{mg} / \mathrm{L})$ and phosphates $(1.0-9.0 \mathrm{mg} / \mathrm{L})$ were detected at all five sites.

\section{Central highland locations}

Sampling at Monteverde Cloud Forest Reserve (Location 4, Fig. 1) occurred twice in the wet season: July 2018 and May 2019. The average WQI at Monteverde Cloud Forest Reserve ranged between 88.0 and $92.0 \%$ in 2018 and 74 and $83 \%$ in 2019 , or good classification. Dissolved oxygen ranged between 7.7 and $8.1 \mathrm{mg} / \mathrm{L}$ (2018) and 7.0 and $8.2 \mathrm{mg} / \mathrm{L}$ (2019). The dissolved oxygen concentrations were higher at all sample sites in 2018. Microorganism activity was recorded by measuring BOD $(0.10-0.20 \mathrm{mg} / \mathrm{L})$ for both years. The values measured for $\mathrm{pH}$ were similar at all seven sites when comparing the 2018 data to 2019 ; the $\mathrm{pH}$ ranges from 6.8 to 7.01 in 2018 and 6.78 to 7.09 in 2019. The 2018 data set for nitrates and phosphates reveals much lower levels than reported for 2019 at the same sites. In 2018 the range of nitrates were non-detectable to $3.0 \mathrm{mg} / \mathrm{L}$, compared to $7.0-9.0 \mathrm{mg} / \mathrm{L}$ in 2019 with an outlier value of $22.0 \mathrm{mg} / \mathrm{L}$ reported at MV2-19. Phosphates showed the same pattern whereby 2018 values were lower (non-detectable to $0.01 \mathrm{mg} / \mathrm{L})$ than those recorded in $2019(1.0-3.0 \mathrm{mg} / \mathrm{L})$. The turbidity levels tend to overlap from year to year (14.20-32.0 NTU in 2018; 15.0-43.0 NTU in 2019); however, the averaged value of turbidity from all the sites is greater in 2019 (29.3 NTU) than 2018 (19.30 NTU). Additionally, the overall averaged WQI dropped from $90.6 \%$ (2018) to $79.8 \%$ (2019).

Sampling in Arenal Volcano National Park (Location 5, Fig. 1) occurred on the adjacent surface water reservoir at six sites that were randomly selected. The dissolved oxygen ranged from 6.60 to $7.50 \mathrm{mg} / \mathrm{L}$ and the $\mathrm{pH}$ ranged from 6.78 to 7.08 . The average turbidity was $28.5 \mathrm{NTU}$ spanning from 29.9 to $36.20 \mathrm{NTU}$. Although phosphates were found to be below $1.0 \mathrm{mg} / \mathrm{L}$ at all sample sites, the nitrates were elevated between 7.0 and $8.0 \mathrm{mg} / \mathrm{L}$. Thus, the turbidity and the nitrates were the two elevated variables that brought down the overall WQI to $85.2 \%$.
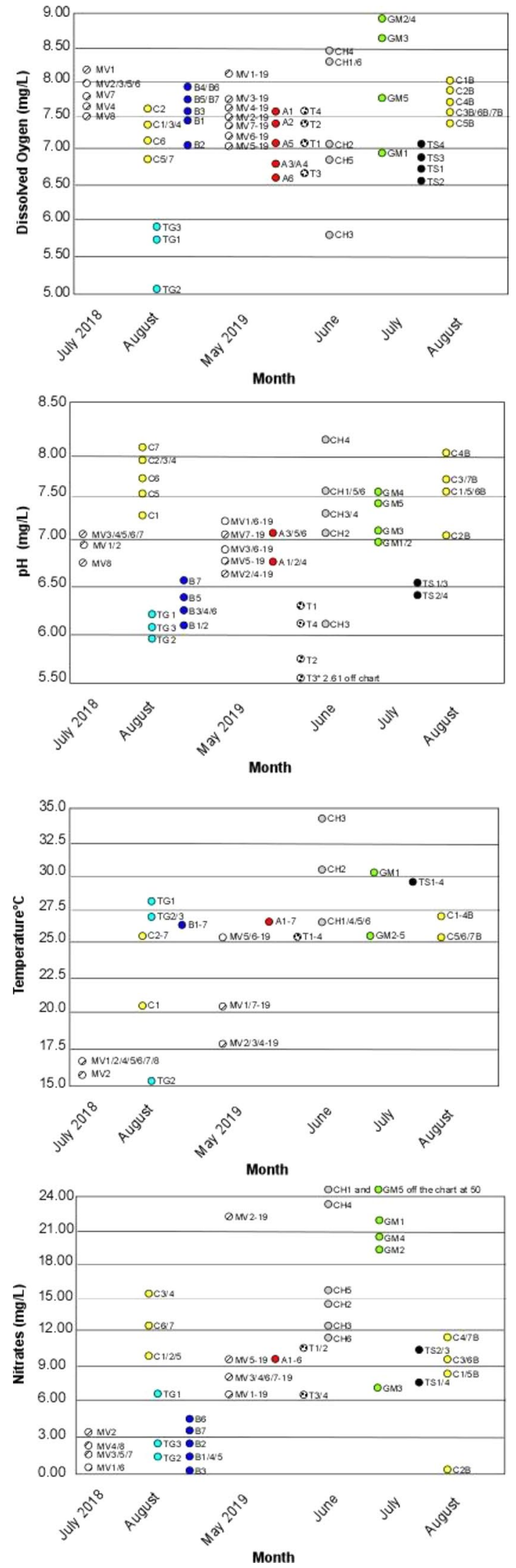

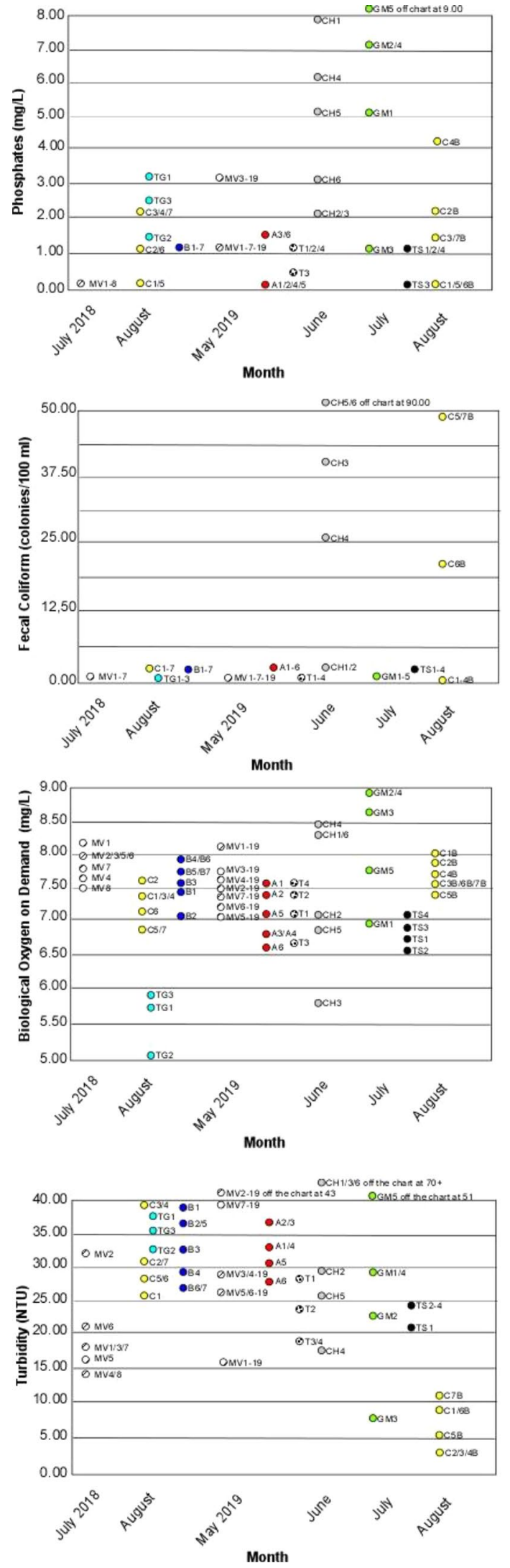

Fig. 3 (continued)
The seven sites sampled at Braulio Carrillo National Park (Location 6, Fig. 1) determined an overall WQI of 81.9\%, or better. The $\mathrm{pH}$ for all sample sites was slightly acidic ranging from 6.13 to 6.39 . The water temperature in all streams sampled was found to be between 22 and $23^{\circ} \mathrm{C}$, while the turbidity was elevated ranging between 28.0 and $38.0 \mathrm{NTU}$. The highest dissolved oxygen level $(7.8 \mathrm{mg} / \mathrm{L})$ was measured at B4 and B6. No fecal coliform levels were reported for this national park.

Of all of the national parks visited for this study, Tenorio Volcano National Park (Location 7, Fig. 1) has a site with the lowest $\mathrm{pH}$ (2.61) logged at T3. The other three sites were also slightly acidic (5.74-6.44). Prominent values were established for nitrates that ranged from 6.0 to $9.0 \mathrm{mg} / \mathrm{L}$, while phosphates remained negligible. The silica-rich waters lent themselves to higher turbidity counts that averaged 22.5 NTU and ranged from 19.0 to 27.1 NTU. The overall WQI at Tenorio Volcano National Park is $78.0 \%$.

\section{Pacific locations}

Despite having the warmest temperatures recorded $\left(29-30{ }^{\circ} \mathrm{C}\right)$ of all the national park locations, Térraba Sierpe National Wetland (Location 8, Fig. 1) had an overall average WQI that was good (80.8\%). The $\mathrm{pH}$ tended to be slightly acidic (6.40-6.50) and the dissolved oxygen low $(6.5-7.0 \mathrm{mg} / \mathrm{L})$. While the phosphates were $1.0 \mathrm{mg} / \mathrm{L}$ or less, the nitrates ranged from 8.0 to $11.0 \mathrm{mg} / \mathrm{L}$.

Seven sample sites were visited at Corcovado National Park (Location 9, Fig. 1) over two field seasons at two different park access points. In 2018 we accessed the southernmost park entrance from HWY 245 and in 2019 our access point was from Sirena Biological Field Station. The overall average WQI in 2018 was $81.0 \%$ and in 2019 was $84.3 \%$. The lower WQI values in 2018 are impacted by the lower dissolved oxygen values (6.7-7.6), and both elevated nitrates (10.0-15.0 mg/L) and turbidity (25.00-40.90 NTU) when compared to the 2019 data. Despite the DO levels being within a normal range $(7.4-7.8 \mathrm{mg} / \mathrm{L})$ at all seven sample sites in 2019 , there were slightly elevated levels of phosphates $(0.0-4.0 \mathrm{mg} / \mathrm{L})$, nitrates $(1.0-11.0 \mathrm{mg} / \mathrm{L})$, and turbidity $(3.0-10.0 \mathrm{mg} / \mathrm{L})$. No fecal coliform was found at sites $\mathrm{C} 1 \mathrm{~B}, \mathrm{C} 2 \mathrm{~B}, \mathrm{C} 3 \mathrm{~B}$, and C4B; however high levels were found at C5B (50.00 colonies/100 ml), C6B (20.00 colonies/100 ml), and C7B (50.00 colonies $/ 100 \mathrm{~mL})$. No fecal coliform was found at any of the sites in 2018.

\section{Multivariate and inferential analysis}

PCA analysis shows that there are three significant dimensions (Dim) within the data (eigenvalues higher than 1.0; Yeomans and Golder 1982), accounting for the $64.9 \%$ of the cumulative variance percentage (Fig. $4 a$ ). Among the 

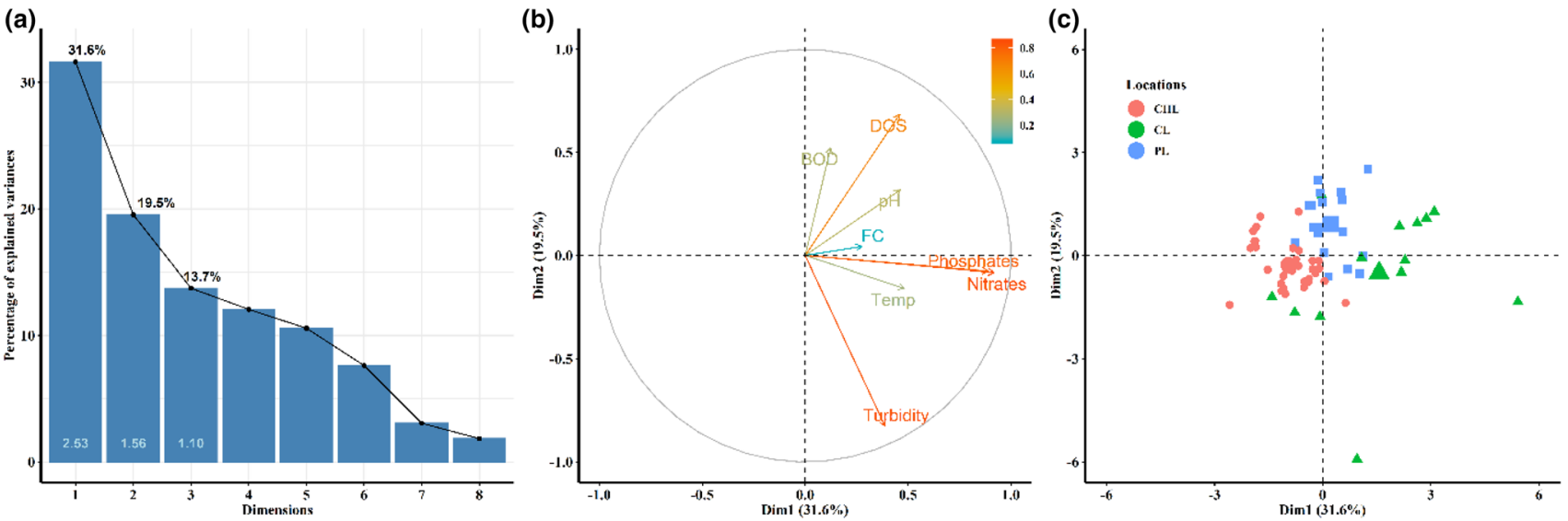

Fig. 4 Principal component analysis comparing a cumulative variance percentage, $\mathbf{b}$ phosphates and nitrates, and $\mathbf{c}$ location

two first Dim (Fig. 4b), phosphates and nitrates have the highest loading factors (>0.75; Liu et al., 2003) in the Dim1 ( 0.89 and 0.92 , respectively), explaining $31.6 \%$ of the data variance; in Dim 2, dissolved oxygen saturation (DOS) and turbidity are the parameters with the highest loading factor (0.68 and - 0.89), and Dim 3 accounts for the $13.7 \%$ of variance. Nevertheless, only fecal coliform has a high factor loading (0.87).

Spatial variability among the national park locations is explained in Fig. 4c. Caribbean locations have more variation within Dim 1; also, it is noticeable that they are well separated from the Pacific coast and Central Highlands, in accordance with major loading factor in phosphates and nitrates. Analysis in Dim2 shows that there are not clearly separations among the locations; however, the majority of points for the Caribbean locations have a negative factor loading in this dimension, relating with the turbidity contributions.

PCA shows that a significant proportion of the total data variance could be explained among the five parameters that had been measured, all of them being related with agricultural activities and/or the lack of a good wastewater sanitation infrastructure (Barrenha et al. 2018; Huang et al. 2017). Phosphates and nitrates are the significant parameters that influence the WQI variability, since these had major contributions in factor loading terms for Dim1. Similarly, DOS and turbidity have significant contribution; however, it is important to stress that positive and negative factor loadings are related with the opposite trend for the variables, which means that increases of turbidity might be linked with decreases of DOS. The latter could be caused by the organic matter that is suspended in high turbidity conditions (MenaRivera et al. 2017).

An evaluation through permutation inferential statistic test was done for the results that were obtained for the WQI as an overall and for the parameters that resulted with the highest loading factors in the significant dimensions of the PCA, revealing that significant difference was found in the majority of those parameters.

Figure 5a shows the distribution for the overall WQI scores. Caribbean locations have the lowest mean and it presents significant differences between the Pacific Coast and Central Highlands $(F=19.30, p<0.05)$. Figure $5 \mathrm{~b}$, c shows the distribution of the WQI scores for nitrates and phosphates. In both cases, CL has significant lower mean values (47 and 19, respectively) than the other locations $(F>11, p<0.05)$. However, it is important to address that the mean distribution for nitrates did not differ for CL and PL (diff $<6.2, p>0.05$ ), the latter suggesting that nitrate input rate and sources in both locations could be similar. DO and turbidity distributions are shown in Fig. 5d, e. Nonsignificant differences were found for the DO mean WQI score $(F=2.4, p>0.05)$; nevertheless, the turbidity mean WQI score has significant differences among the locations, despite that the quality interpretation for all was the same (Medium). Figure $5 \mathrm{f}$ shows the distribution for FC WQI scores. The mean value presents significant differences between CL and PL-CHL $(F=4.5, p<0.05)$. CL presents good quality, while CHL and PL have excellent quality. The latter are principally explained by the results obtained in the Cahuita National Park.

\section{Discussion}

Each of the nine national parks or protected areas have unique hydrologic settings, making strict comparisons of WQI challenging. However, an individual comparison of each system to USEPA and WHO drinking water standards helps to guide the discussion about human health concerns and solutions (Table 1). 


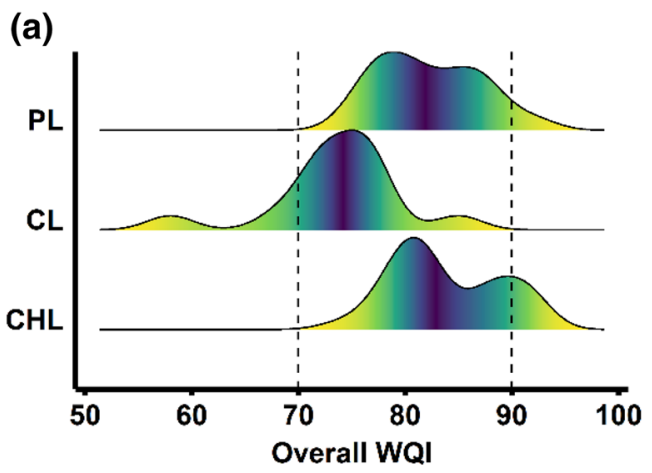

(c)

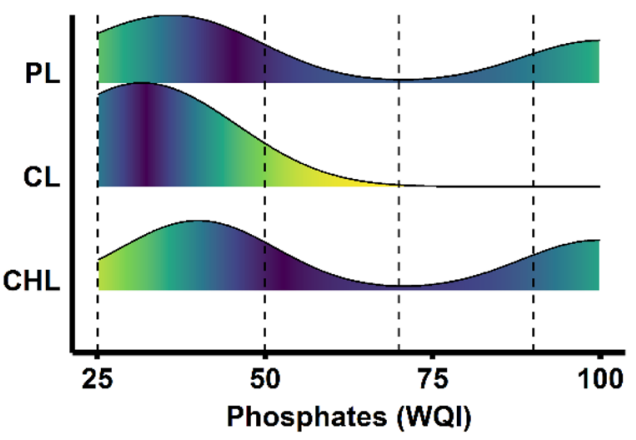

(e)

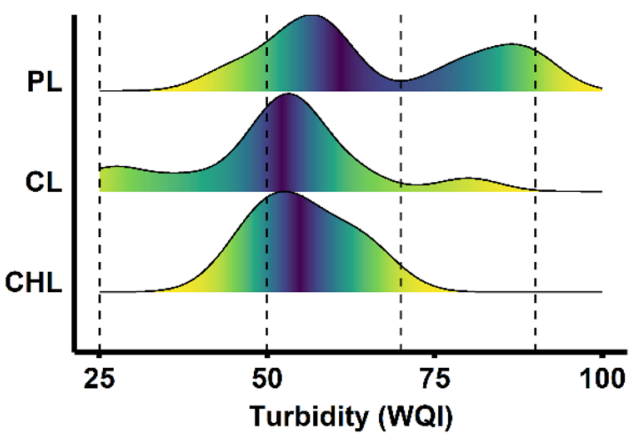

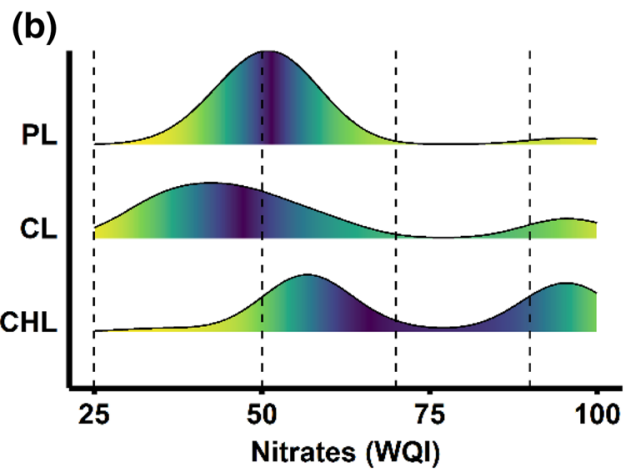

(d)

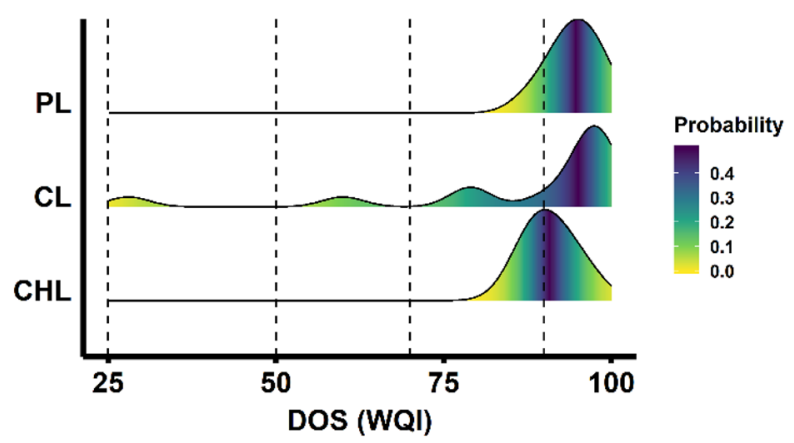

(f)

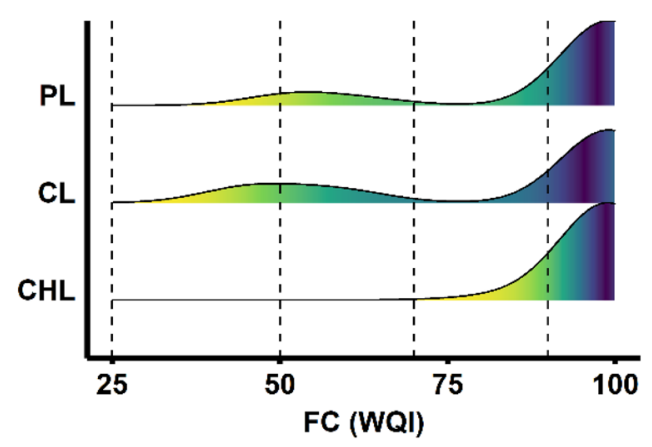

Figures 5 Comparison of Pacific coast (PL), Caribbean coast (CL), and Central Highlands (CHL) with the relationship of a overall WQI, b nitrates, $\mathbf{c}$ phosphates, $\mathbf{d}$ dissolved oxygen saturation, $\mathbf{e}$ turbidity, and $\mathbf{f}$ fecal coliform. The $x$-axis represents values in percentages

A major difference between the eastern and western coasts is the quality of sanitation infrastructure. Notably, a large-scale (Magnitude 7.6) earthquake event occurred in 1991 with its epicenter in Limón (Fig. 1). This event devastated the functioning sanitation systems that have not been completely, or properly, rebuilt. Additionally, due to small population densities and risk of other natural disasters on the Caribbean coast (e.g., flooding), the country has not previously invested financial capital into sanitation. Consequently, all of the sampling locations on the Caribbean coast were found to have the lowest average overall WQI for both 2018 (Tortuguero National Park at 75.0\%) and 2019 (Cahuita National Park, 69.5\%; Gandoca-Manzanillo, $77.6 \%$ ) (Fig. 2). While Tortuguero National Park had the lowest dissolved oxygen reported for the study, the values are likely more representative of stagnant water found in mangrove forest environments than contamination. Similarly, higher amounts of nitrates $(6.0 \mathrm{mg} / \mathrm{L})$ and phosphates $(3.0 \mathrm{mg} / \mathrm{L})$ present in mangrove environments may indicate a buildup effect. This situation can be detrimental to long-term growth rates and sustainability of such forests over time as nitrates and phosphates become immobile (Reef et al. 2010). These effects were also seen at the Pacific coast equivalent, Térreba Sierpe National Wetland. The overall WQI averages of Cahuita National Park and Gandoca-Manzanillo National Park were also greatly affected by the elevated levels of nitrates (upward of $50.0 \mathrm{mg} / \mathrm{L}$ at $\mathrm{CH} 1$ ) and phosphates (upward of $27.0 \mathrm{mg} / \mathrm{L}$ at $\mathrm{CH} 2$ and $\mathrm{CH} 3$ ); however, this input 
Table 1 A comparison chart of USEPA and WHO drinking water standards for the parameters used in the study (USEPA 2010; WHO 2011)

\begin{tabular}{lll}
\hline Chemical parameter & EP $(\mathrm{mg} / \mathrm{L})$ & WHO $(\mathrm{mg} / \mathrm{L})$ \\
\hline Nitrate (NO3) & $0.01-3.0$ & $0.01-5.0$ \\
Phosphate (PO4) & $<0.1$ & 0.1 \\
Physical parameter & & \\
pH & $6.5-8.5$ & $6.5-8.0$ \\
Dissolved oxygen & $4.0-9.0$ & $6.0-8.0$ \\
Turbidity (NTU) & $<5$ & 5 \\
BOD & $<1.0$ & $<1.0$ \\
Temperature & None & None \\
Microbiological parameter & & \\
Escherichia coliform count & $<1.0^{*}$ & $<1.0^{*}$ \\
\hline
\end{tabular}

*Units in cfu/100 mL

is probably the result of upgradient fertilizer input from large-scale banana and pineapple plantations. These values reported for the nitrates and phosphates are the highest reported of all sample locations. Additionally, fecal coliform was found at $\mathrm{CH} 4$ of $\mathrm{CH} 6$ sites in Cahuita National Park ranging from 29.0 colonies $/ \mathrm{ml}$ to 90.0 colonies $/ \mathrm{ml}$. It is plausible that the presence of fecal coliforms come from nearby city sewage drainage as previously mentioned (Mena-Rivera and Quirós-Vega 2018). The only other field sites beyond Cahuita National Park that contained fecal coliform was in Corcovado National Park during the 2019 sampling season.

A drastic change in water quality was seen between the two sampling years at Monteverde Cloud Forest Reserve where the overall average WQI decreased by $14.0 \%$ from 2018 values that were ranked good. This could be due to a reduction in rainfall for the month of May 2019, where the total was $30 \mathrm{~cm}$ lesser than the historical monthly average. Moreover, data suggest that there have been standing impacts on the Monteverde area from the increased use of the Arenal Hydroelectic dam (Nadkami and Wheelwright 2000; Hartshorn et al. 1982). Specifically, when energy is produced the downstream discharge is altered to the Sendero Río as it exits Lake Arenal. The Sendero Río bisects the forest reserve and acts as the main surface water source. In May 2019, dam production was at top facility production which may have had implications on stream holding capacities since rainfall was limited. Moreover, for both years, the nitrates and phosphates were elevated at this forest reserve which could also be the result of fertilizer application at adjacent coffee plantations. Naturally occurring slope instability issues within the park and the adjacent areas in 2019 may have resulted in an increase in sediment supply that contributed to higher turbidity levels.

The lake reservoir nearest to Arenal Volcano National Park was found to have high levels of turbidity and nitrates.
Although this location was sampled during the start of the rainy season, the lack of precipitation for months prior caused the lake to be at extremely low levels. Thus, energy produced at the hydroelectric facility during dry conditions resulted in the mixing of basement sedimentation. Additionally, the temperature influx from geothermal venting from Volcano Arenal may stimulate the growth of nitrate producing microbial life (Sand 2004).

The acidic waters found at Braulio Carrillo National Park result from the highly felsic volcanic ash deposits found in the area from the nearby Barva Volcano that is currently dormant. Likewise, the fine-grained ash gets suspended in the rivers that cross-cut the park and can influence the water clarity.

Similar to Arenal Volcano National Park and Braulio Carrillo National Park, Tenorio Volcano National Park is also influenced by recent volcanic activity. In particular, the park has active fumaroles releasing gaseous sulfur dioxide to the surface which speaks of the acidic waters at some sites. The decrease in water clarity may be a result of silica precipitation that makes the water opaque in Río Celeste.

The water sampled at Térraba Sierpe National Wetland had the highest acidity of any of the nine sample locations. Despite the mangrove forest having the ability to trap calcium-rich shells and offshore coral to make brackish waters alkaline, mangrove soils tend to be slightly acidic due to the presence of sulphur-reducing bacteria that form on their extensive root systems. Likewise, this location also has the lowest recorded dissolved oxygen levels comparatively. Low dissolved oxygen is common in mangrove forests as water becomes trapped to create anoxic zones. Moreover, oxygen found in between the particles of the saturated soil are used up by the decay and respiration of bacteria. The oxygen content is only replenished by the circulation of tidal water and exchange with the atmosphere (Goodwin et al. 2001). Nitrates, although needed in the sustainability of a mangrove forest, are typically found at low levels, as denitrifying bacteria are abundant in mangrove soils. Elevated levels at Térraba Sierpe National Wetland may be the result of major deforestation (loss exceeding 6333 acres) through the disturbance of the nutrient cycle process. Bormann and Likens (1994) explain that land-clearing causes an oversupply of nitrate in the upper soil layers; nitrates that were once stored were then able to be added to the Río Grande de Térraba from surface water runoff. Excess nitrates are of concern, as nutrient enrichment is a major threat to marine ecosystems as it limits the ability for mangroves to grow (Sarker et al. 2019; Reel et al. 2010).

Corcovado National Park is a remote sampling destination on the Osa Peninsula along the Pacific Ocean. Two different sampling locations were visited during the 2018 and 2019 field seasons. The lower value of overall WQI in 2018 (81.0\%) compared to $2019(84.2 \%)$ is the result of higher 
levels of nitrates, phosphates and turbidity. However, these elevated levels are likely to be the result of natural decay processes releasing nitrates, mineralization of compounds in soils and sediments to produce traceable levels of phosphates, quick moving streams that heighten erosion resulting in turbid water conditions and local gray water disposal. Although the overall WQI for 2019 was good, the Sirena Biological Field Station has increasingly become a tourist destination for school groups, whereby increasing the need for waste disposal. Poorly constructed outhouses were built adjacent to the Park's major river (e.g., Río Claro) to meet this demand, but it has led to fecal contamination as seen at $\mathrm{C} 5 \mathrm{~B}, \mathrm{C} 6 \mathrm{~B}$, and C7B.

\section{Conclusions}

The aim of this project was to spearhead forest conservation that is supported by scientific substantiation. This research supports the planning and development of Costa Rica water resources, whereby linking management and sustainable use described by Guzman-Arias and Calvo-Alvarado (2013). Additionally, as the authors have witnessed from their research in emerging countries, it is possible to monitor environmental changes with the application of water quality assessments to gauge system degradation (Jovanelly et al. 2012, 2015).

From this study, we show that the overall health of the surface waters in nine national parks or protected areas are in good standing. In most scenarios, the elevated levels of nitrates, phosphates, or turbidity, or the depleted levels of dissolved oxygen, were the result of natural processes, and not human disturbance. However, in parks that are heavily influenced by dam release (i.e., Monteverde Cloud Forest Reserve), agriculture (i.e., Cahuita National Park) or tourism (i.e., Corcovado National Park, specifically Sirena Biological Station), our study has shown that the well-being of the watersheds is deteriorating by these system impacts. Additionally, climatic variability, especially changes in precipitation patterns, critically influence water quality. For this reason, the authors feel that it is important to establish a monitoring network among these watersheds to have longterm data within the different seasons that will provide a better understanding of the season variability. At present, there are several investigations in urban watersheds (e.g., Mena-River et al. 2017) that show lower levels of WQI in dry season; however, current investigation in non-urban catchments show lower values in the wet season as mainly related by the agricultural runoff.

A major conclusion drawn from this study is that that baseline water quality data are critical for evaluating system integrity and can act as an early indicator to challenges that a forest may face. (An example garnered from this study would be the extremely elevated levels of nitrogen in the Térraba Sierpe National Wetland that could potential cause the ecosystem to perish.) Therein, it needs to be recognized that aquatic systems ultimately support the biodiversity of a forest ecosystem (Hjältén et al. 2016). Stressors such as stream flow regulation, stream channelization, pollution, and climate change affect the water and will translate into diminished ecosystem response.

Whilst Costa Rica is a world leader in the use of carbon neutral energy, biodiversity, and environmental protection, the need for baseline water quality data collection as part of a forest assessment cannot be overlooked and should be deemed compulsory for sustainability and ecosystem security. Physical and chemical data collected on surface water (as done in this study) could be used as a tool to monitor for system change. Moreover, the further use of the WQI to communicate science without jargon in Costa Rica can protect biodiversity by promoting a multi-faceted grassroots approach to conservation that is community centered, whereby local control of monitoring reserves and managing databases motivates pro-environmental behavior and policy. Studies have shown that increased environmental knowledge often leads to civic action in environmental/conservation efforts (Hungerford 2010; Johnson-Pynn and Johnson 2010; Mugisha 2002). Directly relating to Costa Rica, this idea of shared scientific evidence could be used to promote accountability of the ecotourism companies to work toward best practices as suggested by the World Bank 2019) and Garen (2000). Together, these components support long-term, sustainable benefits to people and the environment.

Acknowledgements This project was funded by the National Fulbright Foundation which supported the collaborative project with Nacional Universidad, Heredia, Costa Rica. The authors would like to thank our field supporters Joseph Cook and Allison Burke.

Funding This research was supported by a US Fulbright Research Grant.

Availability of data and material Available.

\section{Compliance with ethical standards}

Conflict of interest All authors declare that they have no conflict of interest.

\section{References}

Acuna-Piedra JF, Quesada-Roman A (2017) Land use and cover changes between 1948 and 2012 in the Térraba-Sierpe National Wetlands Costa Rica. Rev Mar Cost 9(2):9-28. https://doi. org/10.15359/revmar.9-2.1

Allen KE, Vásquez S (2017) Forest cover, development, and sustainability in Costa Rica: can one policy fit all? Land Use Pol 67:212-222 
Alvarado GE, Gans PB (2012) Síntesis geocronológica del magmatismo, metamorfismo y metalogenia de Costa Rica, América Central. Rev Geol Amér Central 46:7-122. https://doi. org/10.15517/RGAC.V0I46.1836

Anderson EP, Pringle CM, Rojas M (2006) Transforming tropical rivers: an environmental perspective on hydropower development in Costa Rica. Aquat Conserv 16(7):679-693. https://doi. org/10.1002/aqc. 806

Barrenha PII, Tanaka MOs, Hanai FY, Pantano G, Moraes GH, Xavier C, Mozeto AA (2018) Multivariate analyses of the effect of an urban wastewater treatment plant on spatial and temporal variation of water quality and nutrient distribution of a tropical mid-order river. Environ Monit Assess. https://doi.org/10.1007/ s10661-017-6386-4

Blair RC, Higgins JJ, Karniski W, Kromrey JD (1994) Multivariate behavioral a study of multivariate permutation tests which may replace Hotelling 's T2 test in prescribed circumstances. Multivar Behav Res 29(2):141-163. https://doi.org/10.1207/s1532 7906mbr2902_2

Bormann FH, Likens GE (1994) Pattern and process in a forested ecosystem. Springer, New York

Bower KM (2014) Water supply and sanitation of Costa Rica. Environ Earth Sci 71(1):107-123. https://doi.org/10.1007/s1266 5-013-2416-x

Brewitt PK, Colwin CL (2019) Little dams, big problems: the legal and policy. WIRES Water 7:1-16

Brown RM, McClellan NI, Deininger RA., Tozer G (1970) A water quality index- do we dare? Water Sewage Works. October 117:339-343

Calder IR (2007) Forests and water-ensuring forest benefits outweigh water costs. Forest Ecol Manag 251(1):110-120. https:// doi.org/10.1016/j.foreco.2007.06.015

Castellón E, Martínez M, Madrigal-Carballo S, Anás ML, Vargas WE, Chavanía M (2013) Scattering light by colloidal aluminosilicate particles produces the unusual sky-blue color of Río Celeste. Tenorio Volcano Complex, Costa Rica

Castillo R, Amador J, Durán AM (2017) Costa Rica Rainfall in future climate change scenarios. AGU Fall Meet Abstr. https:// doi.org/10.1002/essoar.bca73dd28032a2ab.b32e48ac7d934be c. 1

Constantz GD, Bussing WA, Saul WG (1981) Freshwater fishes of Corcovado National Park, Costa Rica. Proc Acad Nat Sci Phila 133:15-19

DeClerck FAJ, Chazdon R, Holl KD, Milder JC, Finegan B, Martinez-Salinas A, Imbach P, Carnet L, Ramos Z (2010) Biodiversity conservation in human-modified landscapes of Mesoamerica: past, present, and future. Biol Conserv 143(10):2301-2313. https://doi.org/10.1016/j.biocon.2010.03.026

Dynesius M, Nilsson C (1994) Fragmentation and flow regulation of river systems in northern third of the world. Science 266(5186):753-762. https://doi.org/10.1126/scien ce. 266.5186 .753

Environmental Protection Agency (EPA) (2016) Healthy Watershed Program: integrating watershed assessment and protection across EPA. https://www.epa.gov/hwp. Accessed 13 Feb 2017

Esquivel-Hernández G, Sánchez-Murillo R, Birkel C, Boll J (2018) Climate and water conflicts coevolution from tropical development and hydroclimate perspective: a case study of Costa Rica. J Am Water Resourc Assoc 13:452-470

Farrell T, Marion JL (2001) Identifying and assessing ecotourism visitor impacts at eight protected areas in Costa Rica and Belize. Environ Conserv 28(3):215-225. https://doi.org/10.1017/S0376 892901000224

Garen EJ (2000) Appraising ecotourism in conserving biodiversity. Yale University Press, New Haven, p 223
Gierszewski PJ, Habel M, Szmanda J, Malgorzatal L (2020) Evaluation effects of dam operation on flow regimes and riverbed adaptation to those changes. Sci Total Environ 710:43-53

Goodwin P, Mehta AJ, Zedler JB (2001) Tidal wetland restoration: an introduction. J Coast Res 27:1-6

Good P (2009) Permutation Test: a practical guide to resampling methods for testing hypotheses. In: Bickel P, Diggle P, Fienberg S, Krickeberg K, Olkin I, Wermuth N, Zeger S (eds.) (2nd edn). Springer, New York. 10.1007/978-1-4757-3235-1

Guswa J, Rhodes AL, Newell SE (2007) Importance of orographic precipitation to the water resources of Monteverde, Costa Rica. Adv Water Resourc 30(10):2098-2112

Guzman-Arias I, Calvo-Alvanrado JC (2013) Planning and development of Costa Rica water resources: current status and perspectives. Techología en Marcha 26(4):52-63

Harpster RE, Alt JN, Schwartz DP (1981) Evidence for Quaternary deformation along the western edge of the Coast Range, southwestern Costa Rica. Geol Soc Am Abstr Programs 13:59 (abstract)

Hartshorn G, Hartshorn L, Atmella A, Gómez L, Mata A, Morales R, Ocampo R, Pool D, Quesada C, Solera C, Solorzano R, Stiles G, Tosi J, Umaña A, Villalobos C, Wells R (1982) Costa Rica: country environmental profile: a field study. Tropical Science Center and U.S Agency for International Development, San José

Hjältén J, Nilsson C, Jørgensen D, Bell D (2016) Forest-stream links, anthropogenic stressors, and climate change: implications for restoration planning. Bioscience 66(8):646-654. https://doi. org/10.1093/biosci/biw072

Huang J, Xu CC, Ridoutt BG, Wang XC, Ren PA (2017) Nitrogen and phosphorus losses and eutrophication potential associated with fertilizer application to cropland in China. J Clean Prod 159:171179. https://doi.org/10.1016/j.jclepro.2017.05.008

Hungerford HR (2010) Environmental education for the 21st century: where have we been? where are we now? where are we headed? J Environ Educ 41(1):1-6

Hunt CA, Harbor LC (2019) Pro-environmental tourism: lessons from adventure, wellness and eco-tourism (AWE) in Costa Rica. J Outdoor Recreat Tour. https://doi.org/10.1016/j.jort.2018.11.007

Jimenez JA (1999) Ambiente, distribución y características estructurales en los manglares del Pacífico de Centro América: contrastes climáticos. In: Yáñez-Arancibia A, Lara-Domínguez AL (Eds). Ecosistemas de Manglar en América Tropical. Instituto de Ecología, A.C. Xalapa, México; UICN/ORMA Costa Rica; NOAA/NMFS Silver Spring MD USA

Johnson-Pynn J, Johnson L (2010) Environmental activism and civic engagement in East African youth. Child Youth Environ 20(1):355-386

Jones IL, Bull JW (2020) Major dams and the challenge of achieving "No Net Loss" of biodiversity in the tropics. Sustain Dev 28:435-443

Jovanelly TJ, Okot-Okumu J, Godwin E (2012) A preliminary investigation to water and soil quality in four forest reserves near Kampala Uganda. J Environ Hydrol 20(10):1-9

Jovanelly TJ, Johnson-Pynn J, Okot-Okumu J, Nyenje R, Namaganda E (2015) Pioneering water quality data on the Lake Victoria watershed impacts to human health. J Water Health (World Health Organization) 13(3):920-930. https://doi.org/10.2166/ wh.2015.001

Karmalkar AV, Bradley RS, Diaz HF (2008) Climate change scenarios for Costa Rican montane forests. Geophys res lett 35(11702):1-5. https://doi.org/10.1029/2008GL033940

Kohlmann B, Roderus D, Ortwin E, Solis A, Soto X, Russo R (2010) Biodiversity conservation in Costa Rica: a correspondence analysis between identified biodiversity hotspots and conservation priority life zones. Rev Mex Biod 81:511-559 
Kolok AS, Beseler CL, Chen XH, Shea PJ (2020) The watershed a conceptual framework for the study of environmental and human health. Env Health Insights 3(1):1-10

Liu CW, Lin KH, Kuo YM (2003) Application of factor analysis in the assessment of groundwater quality in a Blackfoot disease area in Taiwan. Sci Total Environ 313(1-3):77-89. https://doi. org/10.1016/S0048-9697(02)00683-6

Mena-Rivera L, Quirós-Vega J (2018) Assessment of drinking water suitability in low income rural areas: a case study in Sixaola. Costa Rica J Water Health 16(3):403-413

Mena-Rivera L, Salgado-Silva V, Benavides-Benavides C, Coto-Campos JM, Swinscoe TH (2017) Spatial and season surface water quality assessment in a tropical urban catchment: Burio River. Costa Rica Water 9(8):558-568

Mena-Rivera L, Vásquez-Bolaños O, Gomez-Castro C, RodríguezRodríguez A, Sánchez-Gutiérrez R (2018) Ecosystemic assessment of surface water quality in the Virilla River: towards sanitation processes in Costa Rica. Water 10(7):1-16 (Special Issue: Current and Emerging Issues Surrounding Water in the Americas)

Mitchell MK, William SB (2000) Field Manual for Water Quality Monitoring. 12th edn. Kendal Hunt Publishing, Dubuque, Iowa

Mitsch WJ, Tejada J, Nahlik A, Kohlmann B, Bernal B, Hernandez CE (2008) Tropical wetlands for climate change research water quality management and conservation education on a university ácampus in Costa Rica. Ecol Eng 34(4):276-288. https://doi. org/10.1016/j.ecoleng.2008.07.012

Mugisha RA (2002) Evaluation of community-based conservation approaches: Management of protected areas in Uganda. A manuscript submitted to the University of Florida for the PhD. University of Florida, Gainesville

Nadkarni NM, Wheelwright NT (2000) Monteverde: ecology and conservation of a tropical cloud forest. Oxford University Press, New York, p 42 (10.2307/2680213)

Niekerk L, Adams JB, James NC, Lamberth SJ, MacKay CF, Turpie JK, Rajkaran A, Weerts SP, Whitfield AK (2020) An estuary ecosystem classification that encompasses biogeography and a high diversity of types in support of protection and management. Afr J Aquat Sc 45(1-2):199-216

Opperman JJ, Baruch-Mordo S, Carvallo JP, Kammen D, Kiesecker J, Weber C (2019) Sustaining the Last Rivers: the renewable revolution could keep dams off the world's remaining free-flowing rivers. Am Sci 107(5):302. https://doi.org/10.1511/2019.107.5.302

Pereira HR, Gomes LF, Barbosa H (2020) Research on dams and fishes: determinants, directions, and gaps in the world scientific production. Hydrobio 847:579-592

Polanía J (1993) Mangroves of Costa Rica. In: Lacerda LD (ed) Conservation and sustainable utilization of Mangrove Forests in Latin
America and Africa Regions Part 1-Latin America. International Society for Mangrove Ecosystems, Okinawa, pp 129-137

Reef R, Feller IC, Lovelock CE (2010) Nutrition of mangroves. Tree Physiol 30(9):1148-1160. https://doi.org/10.1093/treephys/tpq048

UNESCO (2007) Balancing water of Costa Rica: 1970-2000. International Office of Central America, Latin America, and Caribbean

Quesada-Román A, Pérez-Briceno PM (2019) Geomorphology of the Caribbean coast of Costa Rica. J Maps 15(2):363-371. https://doi. org/10.1080/17445647.2019.1600592

Sarker S, Masud-Ul-Alam MD, Hossain MS, Chowdhurg SR, Sharifuzzamaa SM (2019) A review of bioturbation and sediment geochemistry in mangroves. Geo J 1:1-12

Stan K, Sanchez-Azofeifa A, Calvo-Rodriguez S, Castro-Magnani M, Chen J, Ludwig R, Zou L (2020) Climate change scenarios and projected impacts for forest productivity in Guanacaste Province (Costa Rica): lessons for tropical forest regions. Reg Environ Change 20(1):14. https://doi.org/10.1007/s10113-020-01602-z

United States Environmental Protection Agency (2010) National Primary Drinking Water Standards. Code of Federal Regulation website. https://water.epa.gov/drink/index.cfm. Accessed 29 Apr 2020

Wei G, Yang Z, Cui B, Li B, Chen H, Bai J, Dong S (2009) Impact of dam construction on water quality and water self-purification capacity of the Lancang River, China. Water Resour Manag 23:1763-1780. https://doi.org/10.1007/s11269-008-9351-8

Wells SG, Bullard TF, Menges CM, Drake PG, Karas PA, Kelson KI, Ritter JB, Wesling JR (1988) Regional variations in tectonic geomorphology along a segmented convergent plate boundary pacific coast of Costa Rica. Geomorphology 1(3):239-265. https://doi. org/10.1016/0169-555X(88)90016-5

Winton RS, Calamita E, Wehrli B (2019) Reviews and syntheses: Dams, water quality and tropical reservoir stratification. Biogeosciences 16(8):1657-1671. https://doi.org/10.5194/ bg-16-1657-2019

World Bank (2019). https://data.worldbank.org/. Accessed 1 Feb 2020

World Health Organization (2011) Guidelines for Drinking Water, 4th edn. World Health Organization, Geneva, p 564

Worldwatch Institute (2017) Costa Rica Aims to Become First "Carbon Neutral" Country. https://www.worldwatch.org/node/4958. Accessed 21 Feb 2020

Yeomans KA, Golder PA (1982) The Guttman-Kaiser criterion as a predictor of the number of common factors. Stat 31(3):221. https ://doi.org/10.2307/2987988

Publisher's Note Springer Nature remains neutral with regard to jurisdictional claims in published maps and institutional affiliations. 